\title{
VORWORT / FOREWORD / AVERTISSEMENT
}

Der vorliegende Band 24 der Helgoländer wissenschaftliche Meeresuntersucbungen enthält Vorträge, die anläßlich des Internationalen Helgoland Symposions 1972 der Biologischen Anstalt Helgoland gehalten worden sind. Das Symposion fand in der Zeit vom 17. bis 22. September 1972 auf Helgoland statt. Insgesamt nahmen daran 161 Wissenschaftler aus 20 Ländern teil.

Die Redaktion des Bandes lag in den Händen von Herrn Dr. H.-P. BulnHEIM und mir. Wir danken allen Mitarbeitern sehr herzlich, die uns bei dieser Arbeit unterstützt haben, insbesondere Miss V. Clark, Frau Dipl.-Bibl. I. SchritT und Frau Dipl.-Bibl. B. Sysoew sowie Herrn J. Marschall.

O. KINNE 